\title{
Review on Riverbank Soil Collapse
}

\author{
XU Linjuan ${ }^{1,2}$, LI Junhua ${ }^{1}$, Wang Yuanjian ${ }^{1}$, ZHAO Wanjie ${ }^{1,3}$, JIANG Enhui ${ }^{1, *}$ \\ ${ }^{1}$ Yellow River Institute of Hydraulic Research, Yellow River Conservancy Commission, Zhengzhou 450003, China; \\ ${ }^{2}$ State Key Laboratory of Hydro-Science and Engineering, Department of Hydraulic Engineering, Tsinghua University, Beijing 100084 , \\ China; \\ ${ }^{3}$ North China University of Water Resources and Electric Power, Zhengzhou 450045, China)
}

\begin{abstract}
Bank slope collapse is a kind of natural phenomenon which commonly existed on both sides of alluvial plain rivers. The mechanism of bank collapse is complex, and it is an interdisciplinary frontier research subject. The collapse of the bank slope will lead to the instability of river regime and frequent changes of erosion and siltation, which will cause great harm to river regulation and people's livelihood. Through review of river bank soil collapse at home and abroad, it is concluded that the main influencing factors of river bank soil collapse are the action of water flow and the soil structure of river bank. In addition, the stability of river bank and the numerical simulation of river bank collapse are also studied by scholars. In view of the above research results, the deficiencies of the current research are pointed out and the research directions that should be followed in the future are put forward.
\end{abstract}

\section{Research background}

Alluvial rivers are always in the process of continuous change and development under natural conditions, including the change of vertical erosion and deposition along river bed and river channel transverse deformation (Xie Jianheng, 1989; Jia Dongdong, 2011). Bank collapse is an important manifestation of river channel transverse deformation. It usually occurs in the area directly scoured by water flow, it is an sudden event in the course of river bed evolution that water flow scours, erodes and develops and accumulates on embankments. It belongs to the coupling effect of water and soil boundary (Duan Jinxi, 2004; Yu Minghui, 2010; Zhang Xingnong, 2009).

Bank collapse is a kind of natural phenomenon on both sides of alluvial plain rivers. The mechanism of bank collapse is complicated, and it is an interdisciplinary frontier research subject. It belongs to the lateral evolution of riverbank in river bed evolution and the stability of bank slope in soil mechanics (Davis, 2012). From the form of river bed evolution, bank collapse phenomenon not only runs through the whole river bed-building process, but also develops continuously according to the inherent law of different river types when the river forms a certain shape. Bank collapse is formed by the interaction between river flow and bank soil. On the one hand, the bank slope becomes steeper and unstable because of the action of water flow on the bank. On the other hand, the soil structure and the physical characteristics of soil composition of the river bank determine the anti-scouring of the river bank to maintain the stability of the bank and resist the formation of bank collapse (Yu Minghui, 2008). There are two kinds of internal and external causes (Wang Yangui, 2013). The boundary conditions of bank slope are internal causes, including river bending rate, soil properties and composition, bank slope height and slope (Yu Wenchou, 2008). The river flow dynamics are external causes, mainly including the change of water level in the river channel (Xia Junqiang, 2014; Deng Shanshan, 2015), the seepage effect within the bank slope (Zhang Xingnong, 2015), the scouring effect of longitudinal flow, the circulation and recirculation of bends. After bank collapse, the sloping soil in the river becomes one of the sources of sediment, which makes the sediment inflow and sediment concentration increase rapidly in a short period of time, changes the conditions of sediment inflow in the original channel, and then causes the evolution and development of the downstream channel (Tang Jinwu, 2012).

Hydrodynamic conditions, especially the scouring effect of longitudinal water flow, which are the most important factors affecting erosion, transport of sediments from the bottom and shore and changing their forms. Bank slope failure is a process of repeated circulation that river scouring bank and bank slope collapse. After the soil at the foot of the bank slope is washed away, the rest collapsed into the river, and water flow continues to destroy the temporary bank slope and makes it retreat (Shen Ting, 2005). Moreover, the soil on the bank slope falling into the river channel causes the riverbed scouring and silting deformation as a sudden sediment source (Nagata, 2000; Darby, 1995).

Material composition of riverbed and bank is complex, and they interact with water flow to form a complex system. Therefore, the form and intensity of bank collapse are different in different rivers or in different sections of the same river. Many rivers in our country often have bank collapse, due to the lack of complete and thorough control, resulting in many unstable river regime, frequent changes

* Corresponding author: ehjiang@yrihr.com.cn 
in erosion and siltation, bank erosion and collapse

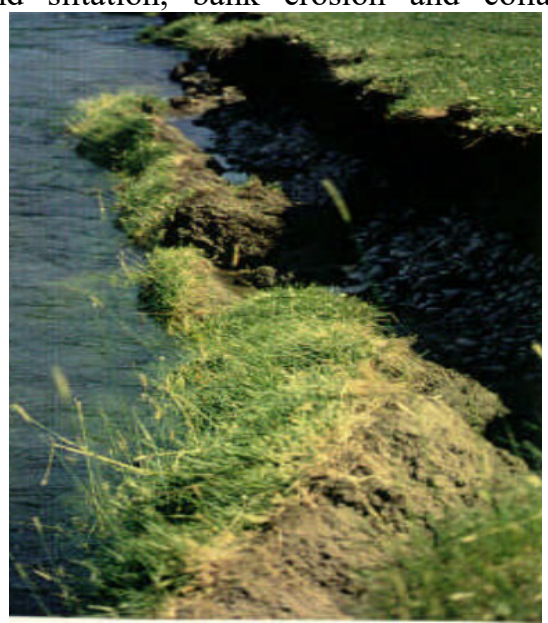

(1) phenomenon is very common and serious in rivers.

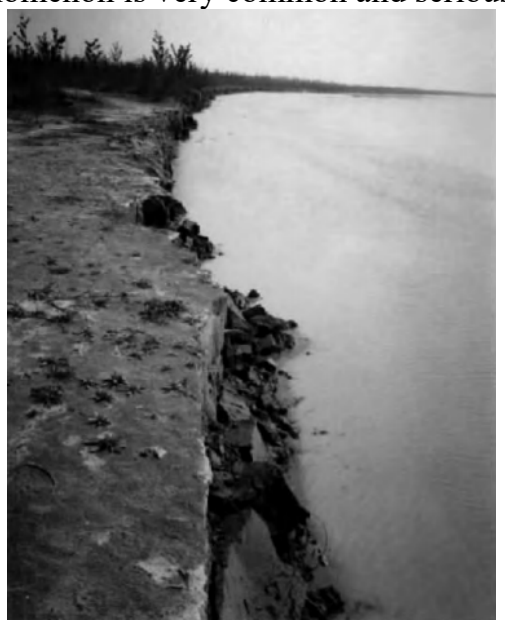

(2)

Fig.1 River bank collapse

broadening model. The model calculates the lateral scour distance of bank slope, and then analyzed whether the bank slope was unstable and collapsed. Huang Bensheng (2002) et al put forward the theoretical model of clayey river bank collapse from the perspective of bank slope stability. Wang Yangui (2003) obtained the similar qualitative knowledge by carring out the generalized model test; the author (2007) also derived the critical height formula for the first and second collapses of broken-line riverbanks on the basis of the stability analysis of riverbanks. Yu Minghui (2008) et al on the basis of summing up the previous research results on bank collapse in the Yangtze River, analyzed emphatically the characteristics and mechanism of bank collapse in different river types, and put forward the calculation model of bank slide, the slope gradient of stable bank slope, and the prediction method of bank collapse. Zhang Xingnong (2009) et al established a generalized slope model based on the original sediment of typical bank collapse sections in the middle and lower reaches of the Yangtze River, and simulated the erosion mechanism and ultimate stability gradient of slope collapse. Sun Jichao (2010) et al studied the stability of bank under scouring action by means of influence deviation and path damage theory, pointed out the evolution and prediction method of bank stability. Zong Quanli (2013) et al established a bank stability calculation model to analyze bank collapse from the view of water flow erosion or bank slope stability, but did not combine the two methods; the author (2014) also proposed the bank collapse calculation of the binary structure of the upper Jingjiang River in different periods (dry period, high water period and recession period), and analyzed the stability of riverbank in different periods and calculated the stability of riverbank under different conditions.

sliding surface must pass through the foot of slope, the simulation results are close to reality and extended to the stretching model of straight reach. Fukoka (1996) carried out the scouring test by digging method in a binary structure bank on a floodplain of Shinkawa River in Japan. The results show that clay collapse can delay further scouring of slope foot by water flow. Osman (1998) and Thorne (1998) based on the hydrodynamic-soil mechanics method of homogeneous bank slope, proposed a channel

\subsection{Influence of riverbank soil structure on bank collapse}

At present, most researches simply studied on the occurrence and development of bank collapse and the critical stability conditions for different riverbank soil compositions (Simon, 2009; Davis, 2012; Stefano, 2003; 
Zhang Xingnong, 2009; Jamieson, 2012; Papanicolaou, 2007; Xia Junqiang, 2013; Nardi, 2012), which are homogeneous or binary structure riverbanks, or without considering the boundary conditions of riverbeds, or the intrinsic factors affecting bank collapse are studied by measuring the evolution law of river channel by establishing mathematical models for the coupling of bank slope and riverbed deformation in alluvial rivers with medium and fine sediment (Nagata, 2000; Darby, 2010; Jia Dongdong, 2014; Chen, 2008), but the research on bank collapse law is not enough according to the river bed boundary conditions. Xia Junqiang (2013) et al quantitatively analyzed the soil characteristics, collapse mechanism and its influencing factors of the lower Jingjiang dual-structure bank of the Yangtze River through indoor geotechnical tests, combining with the nearshore hydrodynamic condition calculation and geotechnical test results. Yue Hongyan (2014) et al carried out a generalized test on the process of bank collapse with binary structure composed of composite plastic sand, and according to the test results, the process of bank collapse was divided into five stages.

\subsection{Influence of hydraulic action on bank collapse}

Hydraulic action is the main external cause of bank collapse. Osman (1998) analyzed riverbed depth and river bank scour respectively, and judged whether the bank collapsed or not by the safety factor. The results of study show that secondary flow will increase the average shear stress of water depth by more than two times (Papanicolaou, et al, 2007). The formation, development process and relevant mechanical mechanism of slope collapse were studied, the results of simulation show that the main effects of water flow on bank slope are erosion at the foot of slope, bank collapse and slope slowing down (Zhang Xingnong, 2009). Jia Dongdong (2011) established the lateral erosion model of flow-slip bank collapse, and verified it by flume test. Jamieson (2012) et al discussed the effects of turbulence and vortices on bank collapse, and found that vortices and scouring zones are coincide. Six groups of tests were carried out in curved flume, the effect of near-shore riverbed composition on viscous bank slope collapse under the same hydraulic action was studied (Yu Minghui, 2016).

The effect of water flow on bank collapse manifest in the following aspects, on the one hand, the change of bank slope gradient changes the stability of bank slope, and on the other hand, the change of flow structure itself after the deformation of river bed, which further accelerates the occurrence of bank slope collapse and the decomposition and transportation of landslides. The positive relation between transverse velocity and river width and water depth is put forward, and it is pointed out that the more concentrated the nearshore velocity, the greater the lateral gradient of the nearshore velocity to the bank, and the steeper the nearshore slope, the more likely the bank slope will lose its stability, and the more likely the bank will collapse (Yu Wenchou, 2008).

The researchers also analyzed the interaction between riparian collapse and riverbed. A series of tests were carried out in curved flume, the interaction process between non-cohesive bank slope erosion and riverbed erosion and deposition and its influencing factors during hydraulic scouring were studied, and the sediment contribution rate of bank collapse and silt bed were futher analyzed (Yu Minghui, et al, 2013). Based on the model of bank collapse with binary structure, a series of tests were carried out in curved channel flume, the transport process of shaped collapse at the foot of concave bank slope and its interaction with the stability of non-cohesive bank slope and the erosion and deposition of river bed were studied (Yu Minghui, et al, 2014). Feng Yu (2013) et al also carried out a series of tests in curved flume to study the slope collapse pattern composed of non-cohesive sediment particles and its interaction with river bed erosion and deposition. Wu Songbai (2014) et al studied the difference of erosion and collapse of bank slopes composed of clay and non-clay soils and their deposition on riverbed, and analyzed the accumulative deposition rate of total erosion and collapse on riverbed.

However, bank slope conditions (i.e. bank slope gradient and soil composition) will affect the stability of bank slope and the collapse of bank slope in natural conditions. Aiming at the bank slope and riverbed composition of homogeneous soil, the process of bank slope collapse, collapse body splitting, fragmentation and transport under the action of hydraulic erosion in curved channel flume was studied, and the interaction law between bank soil transport and riverbed erosion and deposition was further studied (Li Guomin, et al, 2015). $\mathrm{Hu}$ Chengwei (2017) et al carried out a series of experiments in curved channel flume to study and analyze the effects of different bank slope gradient and soil composition on nearshore flow structure, bank slope instability and collapse mode, collapse body transport and its interaction with river bed. The test results show that the decomposition and transport of bank slope collapse and collapse body are closely related to the turbulent kinetic energy of nearshore flow.

\subsection{Mathematical and analog simulation}

From the view of riverbed evolution, bank collapse belongs to the plane deformation of river channel. The phenomenon of bank collapse not only runs through the whole river bed-building process, but also develops continuously according to the inherent law of different river types when the river forms a certain shape. The interaction between beach collapse and riverbed erosion and deposition is complicated and there are many influencing factors. Current research results are relatively simple, or studying riverbank collapse mechanism, or studying riverbed evolution law, In addition, some scholars mostly used mathematical model method to study. Simon (2009) et al simulated and studied the hydraulic process (erosion slope toe) and geological process (gravity collapse) of bank slope erosion with BSTEM model. Sahoo (2011) et al took Jordan Creek River as the research background, attempted to simulate the contribution of riverbank erosion to alluvial channel erosion and 
deposition in the lower reaches by combining dynamic basin simulation model and bank erosion model. Xiao Yi (2012) et al established a mathematical model considering the effects of riparian vegetation and deformation to simulate the change of river morphology and the transformation of river pattern.

\section{Future concerns}

Previous studies have mainly focused on the effects of water flow on sediment transport, and most of them are only from the perspective of soil mechanics, it cannot simulate the impact of water flow on river regime. There is no systematic study on the impact impedance effect of river bank soil on water flow under the different soil, the different soil structure, the different hydrodynamic conditions.

Based on the above research, the author thinks that more attention should be paid to the following aspects in the future. Starting from the different soil structures along the river bank, considering the anti-scour ability of different soil structures to the flow and the influence of different hydrodynamic factors on the bank collapse, the shielding effect of the bank collapse on the toe of slope and the adjustment of the river regime and the influence of the collapsed soil on the downstream river bed morphology evolution should be studied.

\section{Acknowledgments}

This research was supported by National Key R\&D Program of China (2018YFC0407400), and Supported by National Natural Science Foundation of China (51709123, 51479080, 51539004), and Supported by Special Basic Research Fund for Central Public Research Institutes (HKY-JBYW-2018-03), and Supported by Scientific and Technological Development Fund of Yellow River Institute of Hydraulic Research (HKF201706).

\section{References}

1. XIE Jianheng. River bed evolution and regulation[M]. Beijing: China Water Power Press, 1989.

2. JIA Dongdong, ZHANG Xingnong, YING Qiang, et al. Preliminary study on the analytical model for slide collapse of riverbanks[J]. Advances in Water Science, 2011, 22(6): 813-817.

3. DUAN Jinxi, DUAN Wenzhong, et al. Bank collapse and stability analysis[J]. Journal of Wuhan University: Engineering Edition, 2004, 37(6): 17-21.

4. YU Minghui, WEI Hongyan, LIANG Yanjie, et al. Study on the stability of non-cohesive river bank[J]. International Journal of Sediment Research, 2010, 25(4): 391-398.

5. ZHANG Xingnong, YING Qiang, CHEN Changying, et al. Generalized model study on mechanism of riverbank failure[J]. Journal of Hydraulic Engineering, 2009, 40(3): 263-267.

6. DAVIS L, HARDEN C P. Factors contributing to bank stability in channelized, alluvial streams[J]. River Research and Applications, 2012, 30 (1): 71-80.

7. YU Minghui, DUAN Wenzhong, DOU Shentang. Study on the mechanism of river bank collapse[J]. Outstanding Anthology of the Symposium on the 10 anniversary of the 98 floods, 2008.

8. WANG Yangui. Mechanism and analysis mode of sinking failures of river banks[J]. Advances in Science and Technology of Water Resources, 2013, 33(5): 21-25.

9. YU Wenchou, LU Jinyou. Bank collapse and Revetment in the Yangtze River[M]. Beijing: China Water Power Press, 2008.

10. Xia J Q, Zong Q L, Zhang Y, et al. Recent adjustment in reach-scale bankfull channel geometry of the Jingjiang reach owing to human activities[J]. Science China Technological Sciences, 2014, 57(8): 14901499.

11. Deng Shanshan, Xia Junqiang, Li Jie, et al. Influence of the variation of in-channel water levels on the riverbank stability in the Upper Jingjiang Reach[J]. Journal of Hydraulic Engineering, 2015, 46(7): 844852.

12. ZHANG Xingnong, CHEN Changying, JIA Dongdong, et al. Mechanisms of gradual riverbank collapses and simulation study[J]. Advances in Water Science, 2014, 25 (2): 246-252.

13. TANG Jinwu, DENG Jinyun, YOU Xingying, et al. Prediction method for bank collapse of middle and lower Yangtze River[J]. Journal of Sichuan University(Engineering Science Edition), 2012, 44(1): 75-81.

14. SHEN Ting, LI Guoying, ZHANG Xingnong. Numerical analysis of bank failure under lateral erosion[J]. Rock and Soil Mechanics, 2005, (5): 260263.

15. Nagata N, Hosoda T, Muramoto Y. Numerical analysis of river channel processes with bank erosion[J]. Journal of Hydraulic Engineering, ASCE, 2000, 126(4): 243-252.

16. Darby S E, Thorne C R. Development and testing of river bank-stability analysis [J]. Journal of Hydraulic Engineering, ASCE, 1995, 122(8): 443-454.

17. YU Minghui, GUO Xiao. Experimental study on the interaction between the hydraulic transport of failed bank soil and near-bank bed evolution[J]. Advances in Water Science, 2014, 25(5): 677-683.

18. SIMON A, CURINI A, DARBY S E, et al. Bank and near-bank processes in an incised channel[J]. Geomorphology, 2000, 35: 193-217.

19. XIA J Q, WU B S, WANG Y P, et al. An analysis of soil composition and mechanical properties of riverbanks in a braided reach of the Lower Yellow River[J]. Chinese Science Bulletin, 2008, 53(15): 2400-2409.

20. WANG Yangui, KUANG Shangfu. Critical height of bank collapse[J]. Journal of Hydraulic Engineering, 2007, 38(10): 1158-1165. 
21. YUE Hongyan, YU Wenchou. Bank collapse mechanism of Yangtze river[J]. Yangtze River, 2002, 33(8): 20-22.

22. DARBY S E, THORNE C R. Development and testing of river bank-stability analysis[J]. Journal of Hydraulic Engineering, ASCE, 1995, 122(8): 443454.

23. FUKUOKA S. The mechanism of natural bank erosion[J]. Express Water Resources and Hydropower Information, 1996(2): 29-34.

24. OSMAN A M, THORNE C R. River bank stability analysis(I): Theory[J]. Journal of Hydraulic Engineering, ASCE, 1998, 114(2): 134-150.

25. THORNE C R, OSMAN A M. River bank stability analysis(II): Application[J]. Journal of Hydraulic Engineering, ASCE, 1998, 114(2): 151-172.

26. UANG Bensheng, BAI Yuchuan, WAN Yanchun. Model for dilapidation mechanism of riverbank[J]. Journal of Hydraulic Engineering, 2002(9): 49-54, 60.

27. WANG Yangui. Theoretical analysis and experimental study on the collapse mechanism of alluvial river bank beach[D]. Beijing: China Institute of Water Conservancy and hydropower science, 2003.

28. SUN Jichao, WANG Guangqian. Erosion-induced stability of the bank embankment decay[J]. Journal of Tsinghua University: Natural Science Edition, 2010, 50(9): 1346-1349.

29. ZONG Quanli, XIA Jun Qiang, et al. Modeling of the Composite Bank Failure Process Using BSTEM[J]. Journal of Sichuan University: Engineering Science Edition, 2013(3): 69-78.

30. ZONG Quanli, XIA Jun Qiang, XU Quanxi, et al. Soil composition analysis and slope stability calculation for riverbanks in the upper Jingjiang reach[J]. Journal of Hydroelectric Engineering, 2014, 33 (2): 168-178.

31. SIMON A, POLLEN-BANKHEAD N, MACHACEK V. Quantifying reductions of massfailure frequency and sediment loadings from stream banks using toe protection and other means: Lake Tahoe, United States[J]. Journal of the American Water Resources Association, 2009, 45(1): 170-186.

32. DAVIS L, HARDEN C P. Factors contributing to bank stability in channelized, alluvial streams[J]. River Research and Applications, 2012, 30 (1): 71-80.

33. STEFANO D, MASSIMO R. Mechanisms of riverbank failure along the Arno River, Central Italy[J]. Earth Surface Process and Landforms, 2003, 28(12): 1303-1323.

34. ZHANG Xingnong, JIANG Chuanfeng, Chen Changying, etc. Influencing factors for bank collapse in fluvial rivers[J]. Journal of Hohai University, 2009, 37(1): 36-40.

35. JAMIESON E C, RENNIE C D, TOWNSEND R D. Turbulence and vorticity in a laboratory channel bend at equilibrium clear-water scour with and without stream barbs[J]. Journal of Hydraulic Engineering, ASCE, 2012, 139 (3): 259-268.

36. PAPANICOLAOU A N, ELHAKEEM M,
HILLDALE R. Secondary current effects on cohesive river bank erosion[J]. Water Resource Research, 2007, 43 (12): W12418

37. XIA Junqiang, ZONG Quanli, et al. Soil Characteristics of original structure and bank collapse mechanism in lower of Jingjiang[J]. Advances in Water Science, 2013, 24(6): 810-820.

38. NARDI D, RINALDI M, SOLARI L. An experimental investigation on mass failures occurring in a riverbank composed of sandy gravel[J]. Geomorphology, 2012, 163 /164: 56-59.

39. NAGATA N, HOSODA T, MU R AMOTO Y. Numerical analysis of river channel processes with bank erosion[J]. Journal of Hydraulic Engineering, ASCE, 2000, 126 (4): 243-252.

40. DARBY S E, TRIEU H Q, CARLING P A, et al. A physically based model to predict hydraulic erosion of fine-grained riverbanks: the role of form roughness in limiting erosion[J]. Journal of Geophysical Research, 2010, 115 (F4): F04003.

41. JIA Dongdong, HEI Pengfei, SHAO Xuejun, et al. Numerical simulation of bank erosion processes with composite materials and variations in flow structure [J]. Advances in Water Science, 2014, 25(1): 83-89.

42. CHEN D, JENNIFER G D. Case study: twodimensional model simulation of channel migration processes in West Jordan River, Utah[J]. Journal of Hydraulic Engineering, ASCE, 2008, 134: 315-327.

43. XIA Junqiang, ZONG Quanli, XU Quanxi, et al. Soil properties and erosion mechanisms of composite riverbanks in Lower Jingjiang Reach[J]. Advances in Water Science, 2013, 24(6): 810-820.

44. YUE Hongyan, YAO Shiming, et al. Experimental Study on Mechanism of Binary Riverbank Collapse [J]. Journal of Yangtze River Scientific Research Institute, 2014, 31(4): 26-30.

45. YU Minghui, CHEN Xi, et al. Experimental of the influence of different near-bank riverbed compositions on bank failure[J]. Advances in Water Science, 2016, 27(2): 176-185.

46. YU Wenchou. River Boundary Conditions of Mechanism of Bank Failure in Middle and Lower Reaches of Changjiang River[J]. Journal of Yangtze River Scientific Research Institute, 2008, 25(1): 8-11.

47. YU Minghui, SHEN Kang, et al. An experimental study of interaction between bank collapse and river bed evolution[J]. Advances in Water Science, 2013, 24(5): 675-682.

48. FENG Yu, YU Minghui, et al. Study on interaction between non-viscous bank collapse and river bed deformation[J]. Journal of Hydroelectric Engineering, 2013, 32(4): 120-125.

49. WU Songbai, YU Minghui. Experimental study on bank failure process and interaction with riverbed deformation due to fluvial hydraulic force[J]. Journal of Hydraulic Engineering, 2014, 45(6): 649-657.

50. LI Guomin, YU Minghui, CHEN Xi, et al. 
Experimental study on the interaction between bank collapse and riverbed evolution of homogeneous soil[J]. Advances in Water Science, 2015, 26(1): 6673.

51. HU Chengwei, YU Minghui, WEI Hongyan, et al. Experimental study of the influence of bank conditions on bank failure and interaction with riverbed deformation during scouring process[J]. Advanced Engineering Sciences, 2017, 49(2) : 77-85.

52. SAHOO D, MISRA D, BORAH D K, et al. Stream bank erosion contributions to sediment loads in Jordan Creek: DWSM-BE based assessment[R]. Alaska: International Symposium on Erosion and Landscape Evolution, 2011: 739-745.

53. XIAO Yi, SHAO Xuejun, ZHOU Gang, et al. Numerical simulation of river morphology considering the influence and deformation of riparian vegetation[J]. Journal of Hydroelectric power, 2012(36): 149-153. 